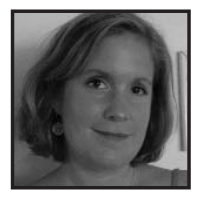

\title{
Poetic Imag(ination): Finding Praxis Through Haiku
}

Sarah K. MacKenzie, Bucknell University

\section{ABSTRACT}

I draw on poetic inquiry to explore my experience using and interpreting haiku within the context of a literacy methods course. From this project I learned that poetry, as a pedagogical tool as well as one of inquiry, opens up spaces for (un)imaginable possibilities to be exposed, moving both teacher and students toward a place of praxis and reflexive agency.

\section{Introduction}

\section{To be of use}

The people I love the best

Jump into work head first

without dallying in the shadows

and swim off with such sure strokes

almost out of sight ...

I love people who harness themselves,

An ox to a heavy cart,

Who pull like the water buffalo,

With massive patience,

Who strain in the mud and much to move

Things forward,

Who do what had to be done,

Again and again. 
I want to be with people who submerge

in the task, who go into the fields to harvest

and work in a row and pass the bags along,

who stand in the line and haul in their places,

who are not parlor generals and field deserters

but move in a common rhythm

when the food must come in or the fire be put out.

The work of the world is common as mud.

Botched, it smears the hands, crumbles to dust.

But the thing worth doing well done

has a shape that satisfies, clean and evident.

Greek amphoras for wine or oil,

Hopi vases that held corn, are put in museums

but you know they were made to be used.

The pitcher cries for water to carry

and a person for work that is real.

- Marge Piercy (1982)

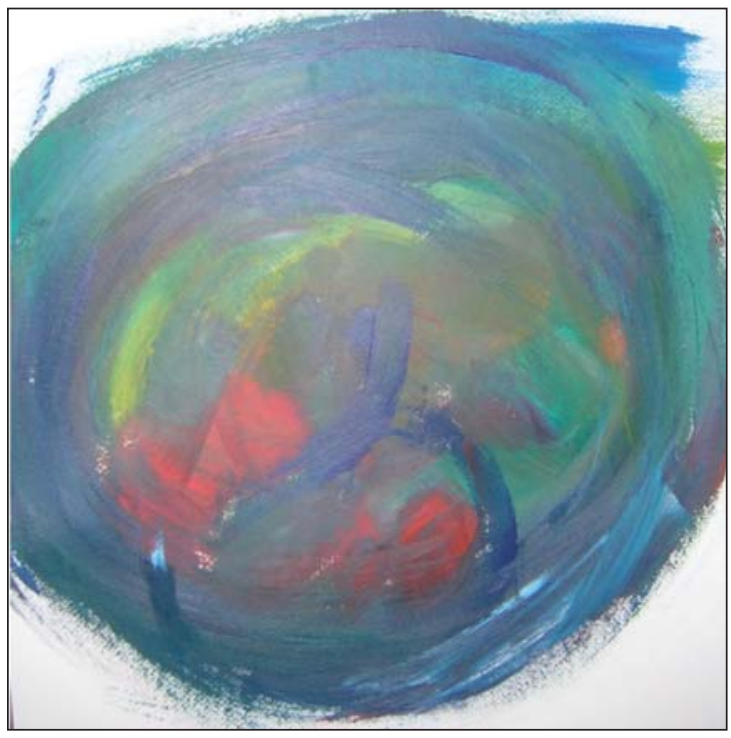

Fig. 1: Circling with(out)

I am a teacher at heart, and there are moments in the classroom when I can hardly hold the joy. When my students and I discover uncharted territory to explore, when the pathway of a thicket opens up before us, when our experience is illumined by the lighting-life of the mind; then teaching is the finest work I know. (Palmer, p. 1, 1998) 
his article shares the story of an illuminated circle, the story of a teacher
educator discovering hope through the recognition of her own limita-
tions of experience and the inspiration of her students (re)searching through self and text to examine the political nature of the practice of teaching. It is a poetic inquiry into the inner and outer workings of teacher, it begins with the "I" but slowly emerges into a "we," be(com)ing a shared story of connection (Leggo, 2008) and newfound awareness of possibility. Prendergast (2009) identifies that,

... to engage in poetic inquiry is as much a calling as it is a method: a calling between the 'I' and the 'Other', a call-and-response, a song that is sung, a voice that wills itself to be heard, in many spaces, both private and public, whispered (or shouted) into multiple ears. (p. xxxv)

As one who often engages in poetic inquiry, I had not necessarily realized how much can truly occur when I pause to examine the initial response of self, finally stopping the claims of knowing, to listen and see through the words and spaces, what exists out/side my consciousness. I have finally arrived at this place, but this is certainly not where I began.

\section{Where I Begin}

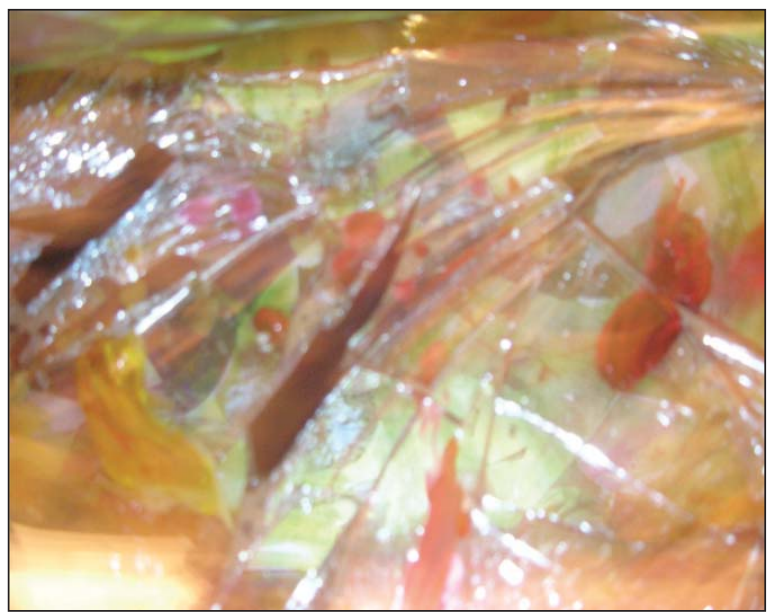

Fig. 2: Broken mirror 


\section{Through the window:}

A young woman sits at her desk, writing. She pauses for a moment looking at her words. Observing her bent figure, focused, one might assume she is committed to her work. Yet if we were to stop and listen to the loud silence, to gaze into her mind, we would find confusion, hesitancy, and a desire to be accepted, recognizable as a knower.

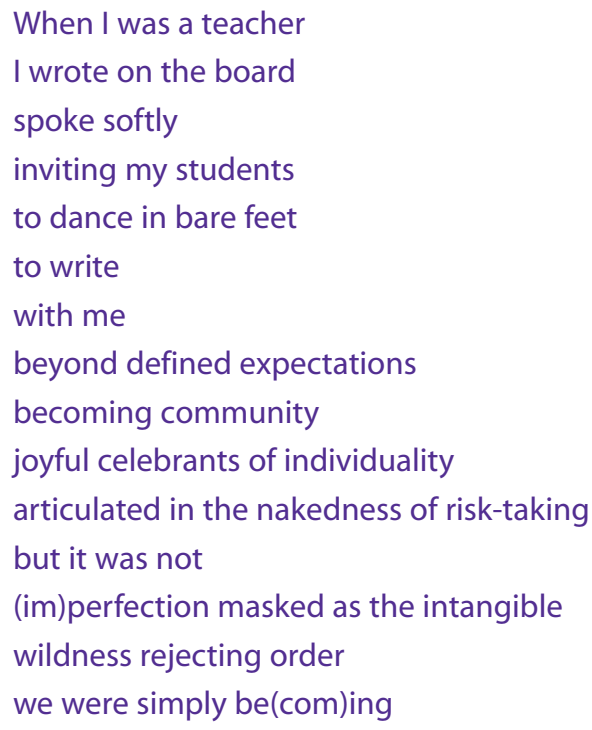

I begin here with the story of my (own) teaching journey, one of praxis, desire, and finally escape. I always begin with this story because it is here where the origins of (my)self as teacher educator arise, it is here where I see failure and possibility. Each day, I return to new landscapes of what once was and what might now be, not for me perhaps, but for my students who have chosen to enter this messy profession called teaching.

Thoughts puddle

tears upon the floor.

The principal shouts

to the little boy

hands caked in dirt

burned by the horror of parents'

actions.

You are not 


\author{
good enough, \\ you cannot go \\ see, experience \\ your teacher says so. \\ And I do not speak, \\ instead caught \\ up in anger \\ silenced \\ and silencing \\ I am lost.
}

I remember myself, an eager beginning elementary school teacher wanting desperately to make a difference, to develop lessons that were engaging while valuing the uniqueness of each student in my classroom. However, as my dreams merged with reality, I was quickly left breathless; isolated in my desire and the reality that perhaps I could not do all that I had imagined. The above poem illustrates this sense of longing and feeling silenced in a holistic sense, but also in a specific sense, when one of my students was not permitted to go on a class field trip because the principal did not trust him, and the principal blamed me. I was overwhelmed by anger, and even as I write this I still find myself somewhat livid at the lost opportunity and in a sense the loss of a young teacher's hope; but I also felt like I had failed my student. This experience is not unique; in fact, I have known many pre-service teachers to feel like they are practicing within a conundrum, where they believe themselves called to make a difference in a space that sputters the status quo, spitting its insipidness upon one's sense of possibility. Often these teachers, like myself, leave the classroom or like so many others I have known, begin to sink into the quicksand of standardization, assessment, and a singularly defined best practice. Teacher attrition is a real problem, and as Darling-Hammond (2003) notes, it is influenced by salaries, poor working conditions, a lack of sufficient teacher preparation and a feeling of having no support or mentors to turn to. As a teacher educator, I feel it is my responsibility to provide my students with multiple opportunities to not only engage with methodology, but also to consider the larger, more systematic, ideological challenges that may play a role in their experiences as teachers. It is my hope that through these types of experiences in the pre-service classroom, that they might develop a sense of praxis and agency within the classroom, thus staying on and truly making a difference. 


\title{
With Intention
}

When my students step into my literacy methods course, I always ask them to identify their goals for the course. Inevitably I find myself bombarded with expectations of facts, formulae, and procedures that will create an exciting and fun classroom, empowering students. While these things are not impossible, there is a lot more that goes into pedagogy. It was this more that got me in trouble as a teacher, leaving me feeling ineffective and voiceless; it was this that made me want to run away. As Palmer (1998) suggests, "... good teaching cannot be reduced to technique; good teaching comes from the identity and integrity of the teacher" (p. 10). As a preservice teacher I had the opportunity to practice technique, what I had not experienced was developing a sense of inwardness that sought thoughtful relationship with the outer other resonating in both student need and the ideologies that shape pedagogical practice. I believe it was the absence of this opportunity that left me illprepared to respond to the challenges that were thrust upon me as a beginning teacher, leaving me to trust my first instinct-to flee. Thus, I believe it is my responsibility as a teacher educator to provide my students with the opportunity to engage both theory and methodology, other story and self story, so that they might become reflexive agents (Shannon, 2001) within a system that can quickly (dis)empower both teachers and students. Giroux (1994) remarks,

To insist that teachers recognize the political nature of their own work can be understood as part of a broader critical effort to make them self-reflective of the interests and assumptions that shape their classroom practices. (p. 37)

\author{
In danger \\ risky thoughts provoked \\ respect us (who)
}

Yes, teaching is indeed political; however until I entered the door of my own classroom I was not aware of the danger or the possibilities that might exist within this space. I did not realize I was not the only one in the classroom-that along with me stood ideology and expectation all ready to yank me in the "right" direction. With all the desire in the world to be an agent of change, I was unprepared to face what that really meant. I was in danger, frozen, without the tools to step outside expectation and reflect upon my position as pedagogue. "I was taught to master a body of knowledge defined ... but I never learned to question ..." (Giroux, p. 39). Thus, as a 
teacher educator, I find myself committed to challenging my students to question, to reflect upon what they read and observe; entering into thoughtful dialogue with text and one another so that they might eventually find the courage to move thoughtfully, responsively, within what can be a tremendously confining space, school. As part of this commitment, I often assign readings that identify the political nature of teaching, that share the underside of the profession, along with the opportunities for praxis, so that students can engage with the "realities" of the classroom, rehearsing their responses so that when they become teachers, they might find themselves able to speak up, to be informed. As Freire (2005) remarks, "If men are unable to perceive critically the themes of their time, and thus to intervene actively in reality, they are carried away by the wake of change" (p.6). Throughout their careers, my students will be influenced by the expectations of others, expectations that shift across time and space, but without the ability to critically engage with these ideas, they are likely to find themselves bound, at a loss or even unaware.

Giroux's (1994) article Teachers, Public Life, and Curriculum Reform is a reading that challenges teachers to become public intellectuals, inviting them to "re-imagine teaching as a part of a project of critique and possibility" (p. 39). Within this article, he shares his own struggles as a teacher, the ill-preparation that focused on mastery of knowledge rather than critical consciousness, and the "realities" of negotiating within the status quo that often defines the educational system. It is often a piece that students find themselves drawn to because it does not simply direct them to become agents, it shares a story, one of challenge that might become their own. It is on this piece, and in particular, the response of my students to the ideas presented and my own emerging insights, that I will focus on throughout the rest of this paper. By identifying my pedagogical approach to engaged reflection and exploring the response of my students, I hope to (re)consider the possibilities of poetry, in this case haiku, as a means to create interrogational spaces - for both pre-service teachers and teacher educators - that move toward praxis.

\section{Choosing Haiku}

Sight chosen

interrogated

without us

We become

we watch each other

truth escapes 
As I have mentioned before, the class that I am writing about was a literacy methods course; we had spent a great deal of time focusing on the value of the writing process in the classroom and talked a tad about the role of poetry in that context, but I was feeling like we needed to delve further into the possibilities of poetry. In honor of National Poetry Month, I decided to invite my students to create haikus as a means to reflect upon Giroux's (1994) article and to consider how poems might in fact be used as an inquiry tool within their own classrooms. We began the class as we usually do, reviewing the agenda and moving into reflecting upon the readings. Students were presented with a set of directions, as well as two model haikus that they could refer to if they found themselves stuck.

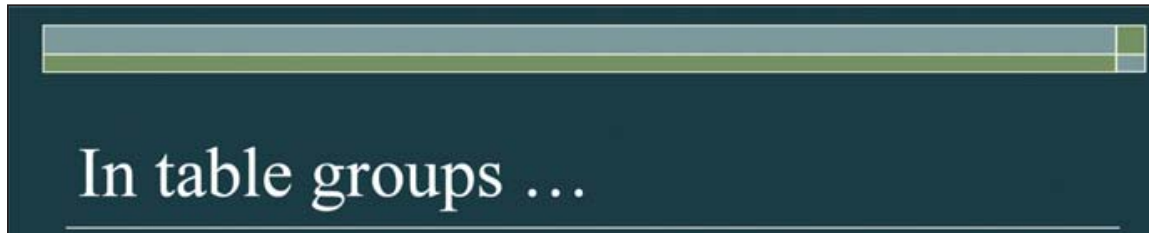

- Identify the big ideas from the reading

- Discuss what strikes you

- Develop 3-5 Haikus that articulate these ideas/response

Silence--a strangled

Telephone has forgotten

That it should ring

-Michael Collings

Freeway overpass--

Blossoms in grafittion

fog-wrapped June mornings

- Michael Collings

Fig. 3: PowerPoint slide

Traditionally, students are first exposed to haiku as a 5-7-5 form where one integrates a season word. As this Japanese form has emerged in the West, it has been adapted, both as a strictly 5-7-5 form to a form that simply consists of a short/long/short pattern. When I introduced the form to my students, for the purpose of this project, I broke with convention and gave them space to play with the patterns, recommending:3-5-3, 5-7-5, short/long/short or long/short/long - they did not 
have to follow any specific form, they just had to maintain some consistent form of pattern and respond to the reading.

Dobyns (2003) remarks:

A work of art gives testimony as to what it is to be a human being. It bears witness, it extracts meaning. A work of art is the clearest nonphysical way that emotion is communicated from one human to another. The emotion isn't referred to, it is re-created. The emotion shows us that our most private feelings are in fact shared feelings. And this offers us some relief from existential isolation. (p. 10)

I wanted students to have the opportunity to be engaged in communal artmaking as a means to engage both the emotional and the intellectual, transcending the powerful "shoulds" that so often inhabit their thoughts. As Brady (2009) intimates, “... poetics is every bit a sensuous-intellectual activity - centering, decoding, reframing, discovering, and discoursing ourselves in ways that show us something of what we are, literally as embodied participants and observers" (xiv). However, recognizing the (un)comfortable nature of creating poetry, engaging in the sensual and the intellectual simultaneously, and the resistance that might arise when asked to engage in something that did not initially seem relevant, I responded to my students' desire to see instructional methods modeled for them; thus using this as an opportunity to model this as a form of transmediation, whereby one moves communicatively across sign systems, translating meaning (Bergoff et al., 2000).

Haiku is a playful poetic form, the word itself meaning "playful phrase" and as such I believed it would create a safe space to enter into the discursive exploration of theory and practice. Students seemed eager to begin, to engage in this playful form of reflection and at the same time there was a sort of reluctance in the air, a reluctance that I interpreted to represent a fear of vulnerability which is so often present within art-making. However, I believed it was important to be present to this discomfort, to negotiate within this space, a space not dissimilar to the one that they would be entering within the profession. Harr (1975) notes that:

Haiku writing is a precise and demanding art, although it looks deceptively easy. It is an expression of a view of nature or of natural events. It invites the reader to share in the event--to co-create it along with the poet. Therefore, haiku makes no effort to teach or philosophize. It is not unduly emotional, but is capable of subtly eliciting emotional response. This is done by understatement, by showing rather than telling. (p. 113) 
While one may initially find discomfort in the act of art-making, there is a structure to haiku that creates a sense of safety on the part of many pre-service teachers, who often find themselves searching for something rational to hold onto within a practice that they are slowly coming to recognize as ambiguous. By using the haiku, I was seeking to find a balance between creating a safe space where students might be faced, through interaction and creative practice, with self and other (Bolton, 1999). It was this active and collective engagement with self, other, and practice that I wanted to elicit, yet I also saw the importance of providing my students with the opportunity to find their own way, discover their own words. Integrating the haiku response into my classroom provided just such an opportunity.

\section{Moving Through Haiku}

After being introduced to the task, students were broken into table groups of 4 or 5 and one group of 6 . Each group chose to approach the task differently: some involved group members brainstorming together the words that they thought were relevant, others involved group members each writing their own haiku and then coming together to share and respond upon the completion of each poem. Either way throughout the process there was lively dialogue and debate, as well as sense of deep engagement with the ideas that Giroux was trying to convey within his article. The following are the haiku poems that they created:

Group One

Oppression

The teacher struggles

For a voice

Finding balance within structure Creativity

Let students explore learning

Working together

A bond that promotes learning

Teacher and students

\author{
Group Two \\ Teach useful knowledge \\ Not only the textbook facts \\ He never learned how
}

\section{Civic competence \\ Teachers are agents of change \\ What do students learn?}

Purposeful teaching
Empowerment of students
Promoting changes

Purposeful teaching

Promoting changes 
Group Three

Traditional ways

Dull, dry writing on the wall

No one really learns

Politics

We're agents of change

Be active

Rethink, restructure

Create a class vision

The role of teachers

\section{Group Four}

Pushed aside

Marginalized by a lack

Of a voice

Empowered for change

Stepping out into the world

Forging a new path

Sit in silence

That is how people learn

"hands off, minds off"

Knowledge to expand

But stopped by those who don't know

We must band together

Confined by rules,

Made without the knowledge

Of how they'd work

Upon the completion of the groups' work, they were eager to share their poems with the rest of the class, proud of their own and their peers' ability to create something tangible and thoughtful. As the poems were shared, themes such as relationship, creativity, rules, reflection, and empowerment were identified and a great deal of discussion ensued in relationship to their role as public intellectuals and what that might mean for their practice. This discussion continued on when they moved into planning their units; it was exciting for them to begin examining how they might empower students, but also what challenges they might come up against. It was a good class, where students had clearly engaged with our essential question (Wiggins \& McTighe, 2005) for the day: Why is it important for teachers to be intellectuals and agents of change? 


\section{Poetic Ponderings}

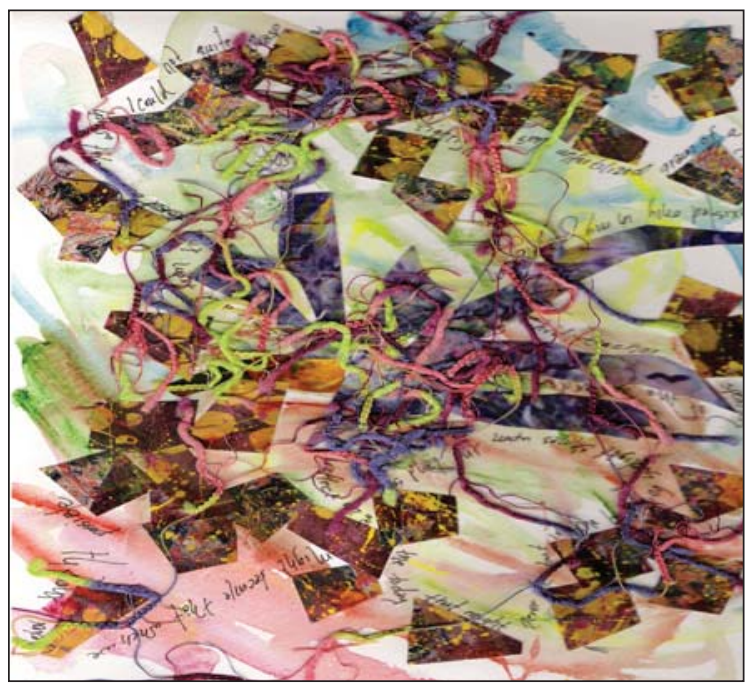

Fig. 4: Stitching sel(f)ves

A life in teaching is a stitched-together affair, a crazy quilt of odd pieces and scrounged materials, equal parts invention and imposition. To make a life in teaching is largely to find your own way, to follow this or that thread, to work until your fingers ache, your mind feels as if it will unravel, and your eyes give out, and to make mistakes and then rework large pieces. (Ayers, 1993)

Despite the positive tone of the class, when I began to engage with the poems of my students, I found myself drawn to specific words:

\section{Marginalized confinement \\ Rules made in silence \\ Oppressed the teacher struggles}

Made without

Knowledge to see change

Stopped by a lack of change

I was nervous, was this kind of agency I hoped for my students, an agency that dwelt within the negative (im)possible, where light was overpowered by dark 
visions of reality? However, stepping back for a while from my reading of poems, taking the time to carefully read each word, I began to recognize that this struggle I imagined was not my students, but rather it had been embedded, stitched, upon my consciousness by my own experience of being a teacher. I felt silenced, I felt marginalized, confined and I ran believing that I might be able to create change within the college classroom. "Exposing” students to the negative realities of teaching, I believed I might better prepare them to speak up. However, as I (re)turned to my students' haikus, what I discovered is that the possibility exists not in the negative, but in finding a balance between problems and how one might negotiate within those spaces. It is not my role to impose my own experience, but rather to create a space for invention and reflexivity. While perhaps my initial, unspoken intention had been a mistake, poetry created the space for my students to come to their own places of knowing within this moment. By playing with the language of haiku, my students had moved beyond the confinement, to acknowledge the challenge, but to see also how their actions might indeed create change within the classroom. Within the haikus my students created, I heard the echo of Marge Piercy's poem, highlighted at the beginning of this article, and realized that indeed, despite the challenges, my students saw that they could be of use.

Davies (2000) notes, that language can be “... understood as the most constitutive force shaping what we understand as possible and what we desire within those possibilities" (p. 170). It is within language that we find ourselves bound, yet it is with/in poetic language that we might become present, (un)bound through the relational aesthetic.

\section{The wind blows}

truth comes into question

definitions along the path

vulnerable

$$
\text { creeping others }
$$

move silently

stealthily

grabbing hold of truths

strangling them

gasping

for breathe

I run

we run

tripping along the way 
But do not stop

look back

for fear

our story

experience

(im)possibility acknowledged

and then

we pause stopping in the moment

drawing on our senses

willing protectors exposed

ready to move in response

ours and theirs

the (be)longing

no longer matters

we have become

a body

moving presently

with/in the blowing wind

The poems created by my students demonstrate a willingness to become vulnerable, a willingness I thought I shared until I stopped to recognize the reflection of my own painful experiences upon my interpretation of their words. I had been clinging for so long to the emotions arising from my own experience that I had forgotten to pause, to see that this was not the only way of experiencing the work of being a teacher. By pausing to take another look, opening up the space of experience and understanding to something that is complicated and collective, I was able to soften the voice of my own intention; to shift the pedagogical lens of my teaching and (re)search so that it might become something collective, where self and other, student and teacher are (dis)connected. It is through this (dis)connection, where stories and understandings are (un)wound that possibility can arise. Through poetic practice the interpretation of text/experience needs not be a mere revalidation of what I already believe I know. Instead, this new acknowledgement of the voice of another, in this case the students in my literacy class, creates space for varied perspectives and possibilities. As I move aware that I am not alone, I gain insight, “... that depth of understanding that comes by setting experiences, yours and mine, familiar and exotic, new and old, side by side learning to let them speak to one another" (Bateson, 1994, p. 14). Todd (2003) reminds me change is not possible without this communal relationship that calls for question and change within acceptance of self in relation to another. 
The Other signifies a limitless possibility for the self, and it is by coming face to face with such limitlessness that the self can exceed its own containment, its own self-identity, breaking the solitude of being for the self. In this view teaching is only possible if the self is open to the Other, to the face of the Other. Through such openness to what is exterior, the "I" can become something different than or beyond, what it was; in short it can learn. (p. 30)

The anger has subsided washed by the winds of our (re)collection of life

The teacher

becomes the learner

enchanted

My students were proud of their creations, eager to share their words with one another-it is my hope that this sense of pride might translate later when even with/in the ideologically violent space of school, they hold on to that sense of hopeacknowledging the fullness and complexity of their position as teachers, a fullness that I had not been ready to see.

\section{Full Circle}

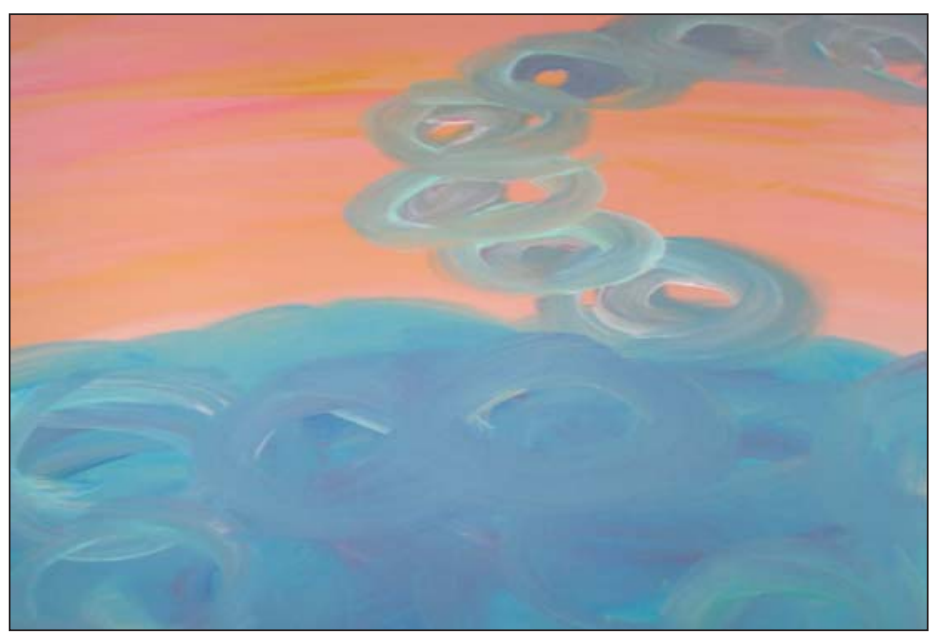

Fig. 5: Resurrection of voice(s) 


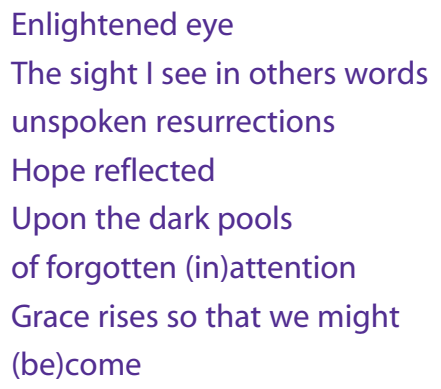

$$
\text { (re)turn }
$$

(re)vise

the public intellect

self

and other

rises with the light of springtime

awakening hope

\begin{abstract}
Poetry and inquiry ask us to listen deeply. We must put ourselves in the context; we must feel, taste, hear what someone is saying. Sometimes we must learn to listen under the words, to hear what is not being said. We must be empathetic, aware, non-judgmental, and cautious, we our participants and ourselves nothing less. (Prendergast, 2009, p. xxvi)
\end{abstract}

The wonderful thing about teaching and research is that they are neverending processes, through each experience we grow, becoming someone new in our understandings. Poetic inquiry and pedagogy serve as a way to further build upon those opportunities, allowing the teacher/researcher the opportunity to engage in a sort of echolocation (Leggo, 2008) where we acknowledge our own positions and stories while navigating with/in those storied positions in relationship to others. And the experience does not end with our own interpretation(s); instead through poetry we speak to and through another who offers new meanings to the words and spaces, new possibilities to practice. Through this project, my initial intention had been to engage my students in poetry writing as a means to think reflexively about the ideological challenges of their practice. It was my desire that the experience would help my students more fully think about the challenges that they might face when they came into the classroom, so that they might be better prepared to respond. I assumed, when reading the haikus that they created, I would see that awareness, a sense of the darkness that would exist around them in practice. What I did not 
anticipate was my own growth in the process, or that my students might in fact teach me something about myself and my own pedagogy through their poetry.

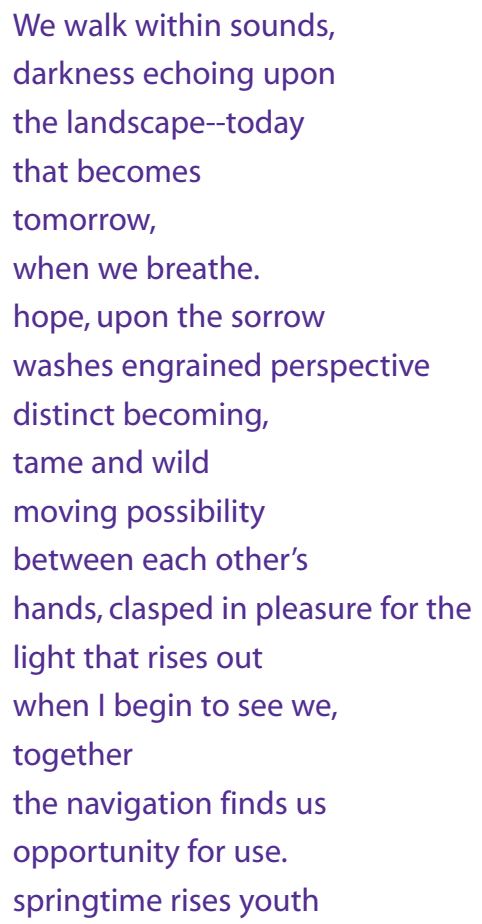

Through this poetic inquiry, I have come to realize how even within the context of the college classroom, my pedagogy and my interpretation of truth remained haunted by the trauma of my own experiences and loss as an elementary school teacher. In addition, I have come to recognize that this did not have to be the truth for me, nor did it have to be so for my students. Instead, pedagogy must rest in a place of resiliency and awareness, where we are willing to see hopefully within practice, not simply with angry recognition of unjust ideology. 


\section{References}

Ayers, W. (1993). To teach: The journey of a teacher. New York: Teachers College Press.

Bateson, C. (1994). Peripheral visions: Learning along the way. New York: Harper Collins Publishing, Inc.

Bergoff, B., Egawa, K.A., Harste, J.C., \& Hoonan, B.T. (2000). Beyond reading and writing: Inquiry, curriculum, and multiple ways of knowing. Urbana: NCTE.

Bolton. G. (1999). 'Every poem breaks a silence that had to be overcome': The therapeutic power of poetry writing. Feminist Review. Contemporary Women Poets. 62, 118-133.

Brady, I. (2009). Forward. In M. Prendergast, C. Leggo, \& P. Sameshima (Eds.), Poetic inquiry: Vibrant voices in the social sciences (pp. xi-xvi). Rotterdam: Sense Publishers.

Darling-Hammond, L. (2003). Keeping good teachers: Why it matters, what leaders can do? Educational Leadership. 60(8), 6-13.

Davies, B. (2000). In scribing body/landscape relations. New York: Altamira Press.

Dobyns, S. (2003). Best words, best order. New York: Palgrave.

Freire, P. (2005). Education for critical consciousness. New York: Continuum International Publishing Group.

Giroux, H. (1994). Teachers, public life, and curriculum reform. Peabody Journal of Education. 69(3), 35-47.
Harr, L.E. (1975). Haiku poetry. Journal of Aesthetic Education. 9(3), 112-119.

Leggo, C. (2008). The ecology of personal and professional experience: A poet's view. In M. Cahnmann-Taylor \& R. Siegesmund (Eds.), Arts-based research in education: Foundations for practice (pp. 89-97). New York: Routledge.

Palmer, P. (1998). The courage to teach: Exploring the inner landscape of a teacher's life. San Francisco: Jossey-Bass.

Piercy, M. (1982). Circles on the water. New York: Knopf.

Prendergast, M. (2009). Introduction: The phenomena of poetry in research. In $M$. Prendergast, C. Leggo, \& P. Sameshima (Eds.), Poetic inquiry: Vibrant voices in the social sciences (pp. xix-xlii). Rotterdam: Sense Publishers.

Shannon, P. (2001). What's my name? In P. Shannon (Ed), Becoming political too: New readings and writings on the politics of literacy education (pp. 112-141). Portsmouth, $\mathrm{NH}$ : Heinemann.

Todd, S. (2003). Learning from the other: Levinas, psychoanalysis, and ethical possibilities in education. Albany, NY: Suny Press.

Wiggins, J., \& McTighe, G. (2005). Understanding by design. Alexandria, VA: ASCD.

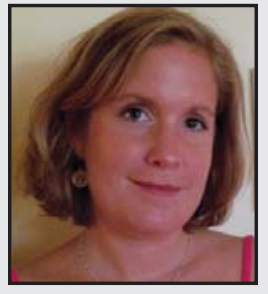

Sarah MacKenzie is an Assistant Professor of Education at Bucknell University in Lewisburg, Pennsylvania, where she mentors student teachers and teaches courses in literacy and educational foundations. Her current research explores artsinformed epistemologies and the ways and spaces in which pre-service teachers (co)write their identities as teachers. 